\title{
Neuro-acanthocytosis: Report of two cases
}

Nöroakantostoz: Iki olgu sunumu

Hüseyin Nezih Özdemir $\quad$ Ahmet Gökçay $\quad$ Figen Gökçay

Ege University, Medical School, Neurology, Izmir, Turkey

\begin{abstract}
Neuro-acanthocytosis (NA), an umbrella term for a group of rare diseases characterized by misshapen erythrocytes (acanthocytes) and neuronal multisystem pathology. Clinical features include choreatic movement disorder, psychiatric manifestations and cognitive decline, and additional features including myopathy, axonal neuropathy and seizures. Herein we report two cases - a 42-year-old woman and a 28-year-old man - from Turkey presented with heterogenous courses of neuro-acanthocytosis.
\end{abstract}

Keywords: Acanthocytosis, chorea, epilepsy, neuropathy.

\section{$\ddot{O z}$}

Nöroakantostoz, yanlış biçimli eritrositler ve nöronal çoklu sistem patolojisi ile karakterize nadir görülen bir grup hastalık için kullanılan şemsiye bir terimdir. Klinik özellikleri koreik hareket bozuklukları, psikiyatrik bulgular ve bilişsel gerilemeye ek olarak myopati, aksonal nöropati ve nöbetleri içerir. Burada Türkiye'den, nöroakantozun farklı klinik seyirleri ile prezente olan iki olgu -42 yaşında bir kadın ve 28 yaşında bir erkek- sunulmuştur.

Anahtar Sözcükler: Akantostoz, kore, epilepsi, nöropati.

\section{Introduction}

Neuro-acanthocytosis (NA) syndromes are diseases characterized by the misshaped erythrocytes (acanthocytes) and progressive degeneration of the central nervous system in particular basal ganglia (1). Predicted prevalence is less than 1 to 5 per $1^{\prime} 000$ '000 patients for each disease (1). A wide variety of symptoms can be seen in NA syndromes (2). Common features include hyperkinetic movement disorders, dysarthria, dysphagia, seizures, peripheral neuropathy, dementia psychiatric symptoms (2). There isn't a curative treatment for the diseases; the symptomatic approach is suggested (2). The disorders frequently present with hyperkinetic movement disorder (2). The most often presenting movement disorder is chorea (3). We present these cases because they show the different clinical characteristics of the same disease.

\section{Case Presentation}

Case 1: A 42-year-old woman admitted to our department with involuntary movements in arms and legs. These movements were rapid contractions affecting the distal limbs. Also mouth and tongue were affected. Her complaints started three years ago and showed progressive course. Her walk had been hampered with involuntary movements. She was wheelchair bound because of frequent falls. She had a history of generalized tonic-clonic seizures started 25 years old of age. She had been treated with phenytoin $100 \mathrm{mg}$ three times a day and her seizures had been controlled well. On neurological examination, she was cooperated and oriented. The strength of all muscles was normal. Deep tendon reflexes were absent bilaterally. She denied sensory deficit. She wasn't able to walk due to involuntary flexion of knees.

\footnotetext{
Corresponding author: Hüseyin Nezih Özdemir

Ege University, Medical School, Neurology, Izmir, Turkey

E-mail: huseyinnezihozdemir@gmail.com

Received: 26.01.2019

Accepted: 29.03.2019
} 
She had orofacial dyskinesias and generalized choreic movements. Liver, renal, thyroid tests, lipid profile, serum $\mathrm{Cu}$ and ceruloplasmin levels within normal limits. Creatine phosphokinase level was $428 \mathrm{IU} / \mathrm{L}$ (high). EMG was suggestive of mild axonal sensory neuropathy. EEG was unremarkable. Cranial MRI was normal.

Peripheral blood smear showed increased acanthocyte counts. Acanthocyte percentage was higher than $10 \%$. Lipoprotein electrophoresis didn't show the absence of beta-lipoproteins. Her vitamin $\mathrm{E}$ level was normal. Abdominal ultrasonography was normal. Neuropsychological tests showed major cognitive impairment (CDR:1) Cardiac and ophthalmologic examinations were normal. She diagnosed as NA. At the beginning she was treated with trihexyphenidyl $2.5 \mathrm{mg}$ two times a day. Two weeks later started using trihexyphenidyl $5 \mathrm{mg}$ two times a day. On follow up a month, her symptoms improved, and she was ambulatory.

Case 2: A 28-year-old man presented with involuntary movements in the orofacial region. He had involuntary jaw and tongue movements which started two years ago. The severity of symptoms was constantly progressing. He had difficulty in swallowing. The liquids were leaking through the lips while drinking. His mother reported his speech became slurred. $\mathrm{He}$ complained about tongue and lip wounds caused by biting. He was using a napkin between his teeth to avoid biting. Before our evaluation, he had been treated with sertraline $50 \mathrm{mg} /$ daily at a local psychiatric clinic. He did not have the history of seizures. On neurological examination, he had facial dyskinesias mimicking chewing. This dyskinesias were associated with the brief closure of his eyes. His speech was dysarthric and frequently interrupted with tongue biting. Tongue protrusion dystonia was seen occasionally. Mild phonic tics were observed. His ocular movements were normal. His muscle strength remained normal. His deep tendon reflexes were absent. He denied sensory deficit. His blood chemistry and hemogram were unremarkable. Lipid profile within normal limits. Peripheral blood smear showed increased acanthocyte counts. Acanthocyte percentage was higher than $10 \%$. Lipoprotein electrophoresis didn't show the absence of beta-lipoproteins. His vitamin $E$ level was normal. Abdominal ultrasonography was normal. The neuropsychological tests showed mental retardation, His IQ point was 59. Cardiac and ophthalmologic examination were normal. He diagnosed as NA. Tetrabenazine $25 \mathrm{mg}$ twice a day was prescribed. After a month he started to use $50 \mathrm{mg}$ twice a day. He used tetrabenazine for three months. It was not beneficial.

Written informed consent was obtained from the patients who participated in this study.

\section{Discussion}

Neuro-acanthocytosis syndromes are a group of rare diseases including, chorea-acanthocytosis, McLeod syndrome, Huntington disease-like 2, pantothenate kinase-associated neurodegeneration, Abeta and hypobetalipoproteinemia and aceruloplasminemia (2). This heterogeneous group of disorders has common clinical features presenting frequently as a hyperkinetic movement disorder (2).

The most often presenting movement disorder is chorea. Orofacial dystonia is also common. Tongue protrusion, tongue, and lip biting cause ulcers in lip and tongue. Difficulty swallowing is called "feeding dystonia" and it may cause weight loss. The symptoms are progressive (3).

Patients may develop Frontal lobe syndrome-like symptoms, which include loss of executive functions, disinhibition, and loss of social inhibition. Seizures occur in half of the patients; it can be presenting symptom (3).

On neurological examination, absence of deep tendon reflexes and loss of vibration sense can be found resulting from neuropathy. The pyramidal tracts are not affected (3).

Although there is no genetic evidence, the clinical features are suggestive of choreaacanthocytosis. The combination of chorea and other movement disorders, seizures, neuropathy and neuropsychiatric symptoms in association with elevated creatine kinase levels are strongly suggestive of chorea-acanthocytosis (3).

For limb chorea and truncal chorea classic antidystonia medications, including anticholinergics (e.g., trihexyphenidyl), benzodiazepines (e.g., clonazepam), and baclofen can be chosen (4). Tetrabenazine is an option, but it is not always effective (4). Tetrabenazine may diminish feeding dystonia and tongue protrusion. Botulinum toxin injected into the musculus genioglossus may be used to diminish tongue protrusion (4). 


\section{References}

1. Jung H, Danek A,Walker RH. Neuroacanthocytosis Syndromes. Orphanet J Rare Dis. 2011; 6: 68.

2. Peikert A, Danek A, Hermann A. Current state of knowledge in Chorea-Acanthocytosis as core Neuroacanthocytosis syndrome. Eur J Med Genet. 2018; 61 (11); 699-705.

3. Baeza VA, Dobson-Stone C, Rampoldi L, et al. Chorea-Acanthocytosis. GeneReviews [serial on the internet]. 2014 [cited 20 Feb 2019]. Avaible from https://www.ncbi.nlm.nih.gov/books/NBK1387/

4. Walker RH. Management of Neuroacanthocytosis Syndromes. Tremor Other Hyperkinet Mov (N Y). 2015; 5: 346. 